mentaries on our present world situation, however, it is permeated with a serenity that is based on certainty, an optimism that is based on a firm belief in the value and goodness of each imperfect person.

Pacem in Terris represents a breakthrough in our reactions, which tend to be static and rigid. As such it is welcome to all those who recognize the need to break through their own particular patterns of thought. What is needed now, of course, is the effort to apply what are, after all, not free-floating generalities but concrete suggestions. The most fitting tribute to the remark. able man who was John XXIII, to this sweet and beautiful spirit, is to accept with gratitude and apply with diligence what he has so generously offered, in order that man and the conditions in which he lives may be uplifted.

\section{from Pacem in Terris}

"Beginning our discussion of the rights of man, we see that every man has the right to life, to bodily integrity, and to the means which are necessary and suitable for the proper development of life; these are primarily food, clothing, sheiter, rest, medical care, and finally the necessary social services. Therefore a human being also has the right to security in cases of sickness, inability to work, widowhood, old age, unemployment, or in any other case in which he is deprived of the means of subsistence through no fault of his own."

"Every human being has the right to honor God according to the dictates of an upright conscience, and therefore the right to. worship God privately and publicly."

"The right to private property, even of productive goods, also derives from the nature of man. This right, as We have elsewhere declared, is an effective aid in safeguarding the dignity of the human person and the free exercise of responsibility in all fields of endeavor. Finally, it strengthens the stability and tranquillity of family life, thus contributing to the peace and pros. perity of the commonwealth.

"However, it is opportune to point out that there is a social duty essentially inherent in the right of private property."

“... the conviction that all men are equal by reason of thier natural dignity has been generally accepted. Hence racial discrimination can in no way be justified, at least doctrinally or in theory. And this is of fundamental importance and significance for the formation of human society according to those principles which We have outlined.... For, if a man becomes conscious of his right, he must become equally aware of his duties. Thus he who possesses cer- tain rights has likewise the duty to claim those rights as marks of his dignity, while all others have the obligation to acknowledge those rights and respect them."

". . the relations of the citizens with each other, of citizens and intermediate groups with public authorities, and finally of the public authorities with one another, are often so complex and so sensitive that they cannot be regulated by infexible legal provisions, Such a situation therefore demands that the civil authorities have clear ideas about the nature and extent of their official duties if they wish to maintain the existing juridical structure..."

". . one must bear in mind that, even though the monstrous power of modern weapons acts as a deterrent; it is to be feared that the mere continuance of nuclear tests, undertaken with war in mind, will prove a serious hazard for life on earth.

"Justice, then, right reason and humanity urgently demand that the arms race shouid ceuse; that the stockpiles which exist in various countries should be reduced equally and simultan. eously by the parties concerned; that nuclear weapons should be bamned; and that a general agreement should eventually be reached about progressive disarmament and an effective method of control."

"Requirements of the common good are necessarily connected with the structure and function of political authority. The moral order not only indicates the need for political authority, but requires that this authority be effective for the goal in view. Today the universal common good poses problems of world-wide dimensions. There is need, therefore, for a public authority which can operate effectively on a world-wide basis, coping with situations beyond the capacity of individual countries or regions." 